\title{
Jaroslaw Sozański, Prawa czlowieka w Unii Europejskiej (po Traktacie Lizbońskim), Polskie Wydawnictwo Prawnicze, Warszawa-Poznań 2011, ss. 270.
}

Prawa człowieka, a zatem także ich ochrona, stanowią ważny problem współczesnej rzeczywistości. Niezbędne są działania państw nie tylko w ramach ich ustawodawstwa wewnętrznego, lecz także regulacje międzynarodowe. Dokumenty takie powstały do tej pory między innymi w ramach Rady Europy czy Organizacji Narodów Zjednoczonych. Także państwa członkowskie Unii Europejskiej dostrzegły konieczność podejmowania działań na rzecz ochrony praw człowieka, szczególnie po wejściu w życie 1 grudnia 2009 roku Traktatu Lizbońskiego. Tematykę tę przybliża publikacja Jarosława Sozańskiego zatytułowana Prawa czlowieka w Unii Europejskiej (po Traktacie Lizbońskim) wydana nakładem Polskiego Wydawnictwa Prawniczego.

Tytuł w pełni odzwierciedla zawartość publikacji. Każdy z rozdziałów prezentuje odrębne kwestie stanowiące łącznie spójną całość. Poruszają one najważniejsze kwestie związane z ochroną praw człowieka. Książka podzielona jest na jedenaście rozdziałów poprzedzonych wstępem, w którym Autor prezentuje poruszane w pozycji zagadnienia.

Po ostatnim z rozdziałów zamieszczona została część zatytułowana Konkluzje. Pozycję wzbogacono aneksem, w którym znajduje się treść Karty Praw Podstawowych oraz opracowane do niej Wyjaśnienia.

Autor poddaje analizie problematykę ochrony praw człowieka, rozpoczynając od przeanalizowania praw człowieka w kontekście obowiązujących traktatów (Nowe ujęcie praw człowieka w Traktacie Lizbońskim). W rozdziale drugim, Prawa czlowieka i ich rozwój-podstawowe pojęcia, Autor podjął się zdefiniowania szeregu terminów dotyczących praw człowieka. Odrębne rozdziały Autor przeznaczył na omówienie zasady niedyskryminacji (Zasada niedyskryminacji w prawie wspólnotowym i unijnym) oraz ochronie praw mniejszości (Ochrona praw mniejszości). Nie pominął w swoich rozważaniach Karty Praw Podstawowych stanowiącej najważniejszy dokument dotyczący ochrony praw człowieka wypracowany w ramach Unii Europejskiej, której poświęcił jeden z rozdziałów. Znalazły się również artykuły poświęcone strukturom Unii Europejskiej oraz programom istotnym dla badanego zagadnienia (Struktury unijne a ochrona praw czlowieka). W rozdziale pt. Europejska konwencja praw czlowieka i inne standardy międzynarodowe $w$ acquis pod rozważania Autor poddał relacje pomiędzy Unią Europejską a Europejską Konwencją Praw Człowieka. Zwrócił uwagę także na inne konwencje dotykające tej materii oraz na Europejską Kartę Społeczną. Autor nie pominął w książce ochrony praw człowieka zarówno na drodze sądowej, jak i pozasądowej. O zagadnieniu tym traktuje rozdział dziesiąty. Ostatni z rozdziałów, Ochrona praw czlowieka w cyberprzestrzeni a Unia, poświęcony został zjawisku cyberprzemocy.

Publikacja $\mathrm{z}$ całą pewnością jest istotna ze względu na aktualność i znaczenie badanego zagadnienia. Blisko trzystustronicowa pozycja w kompleksowy i wyczerpujący sposób ujmuje analizowaną tematykę. Książka w sposób ciekawy i przystępny omawia niezwykle ważny element rzeczywistości, jaki stanowią prawa ezłowieka. Struktura pracy pozwala czytelnikowi w łatwy sposób odnaleźć najistotniejsze informacje. Autor wielokrotnie także w przypisach thumaczy poszczególne zagadnienia.

Autor skorzystał z licznych publikacji krajowych oraz zagranicznych, odwołując się także do najważniejszych dokumentów dotyczących praw człowieka. Część materiałów dostępnych jest za pośrednictwem Internetu. 